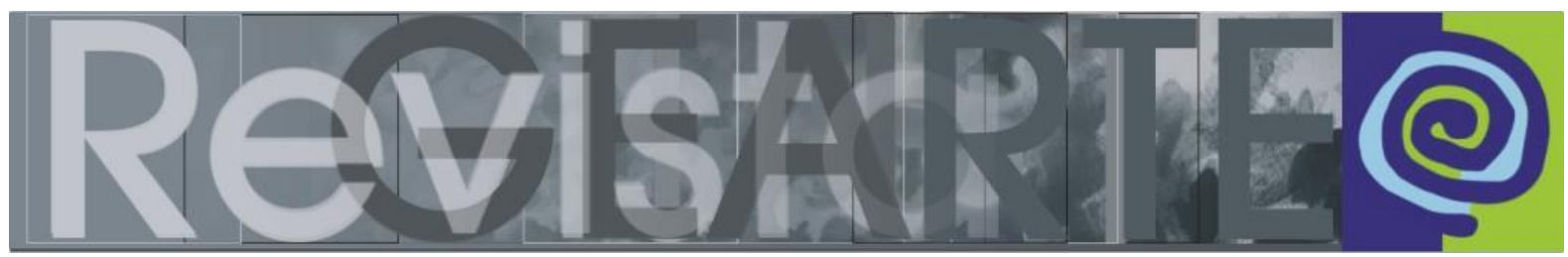

ISSN 2357-9854 | e-ISSN 2596-3198 (online)

\title{
Educación por el Arte vs. Colonización de la Subjetividad
}

Victor Kon

(Consejo Latinoamericano de Educación por el Arte - CLEA, Argentina)

¿Es la Educación por el arte una utopía irrealizable? Veamos: La educación por el arte pregona que los seres humanos nos educamos en múltiples espacios a lo largo de la vida, de los cuales la escuela es solo uno de ellos; que educarnos es adquirir conocimiento significativo: Desarrollando todas nuestras capacidades, adquiriendo identidad, dejando en libertad nuestra creatividad, permaneciendo fieles a los más prístinos valores humanos; participando de nuestra comunidad defendiendo derechos propios y respetando los ajenos. Con arte, un faro que da sentido a nuestros actos, aprendemos a ser mejores personas, a tener una existencia más bella y trascendente.

Pensemos desde nuestra condición de latinoamericanos. Es a partir de 1492, desde su llegada a nuestras tierras, que Europa se erigió como modelo hegemónico tratando de eliminar todo vestigio de las culturas originarias y con dos objetivos básicos: apropiación de las riquezas, especialmente el oro y la plata, y colonizando las subjetividades para naturalizar el saqueo y generar dependencia. Riquezas que cimentaron el camino europeo hacia la revolución industrial y el capitalismo. Colonización de las subjetividades que persistió por siglos, aún conquistada la independencia política, incluso hasta nuestros días.

Desde ese momento, esta Sociedad continental se ha conformado a partir de dos imaginarios sociales heterogéneos según lo señala C. Castoriadis: 1) El imaginario social democrático caracterizado por los ideales y modelos de independencia, igualdad frente a la ley, solidaridad, caminos propios y participación. Lo sintetizó Simón Rodríguez, que fuera maestro de Simón Bolívar: "Inventamos o erramos". Lo cantó en cielitos Bartolomé Hidalgo El bardo de artigas y 2) El imaginario social devenido capitalista hacia fines del siglo XIX caracterizado por la acumulación de riqueza por unos pocos, especialmente de tierras, el individualismo, el racismo, la 


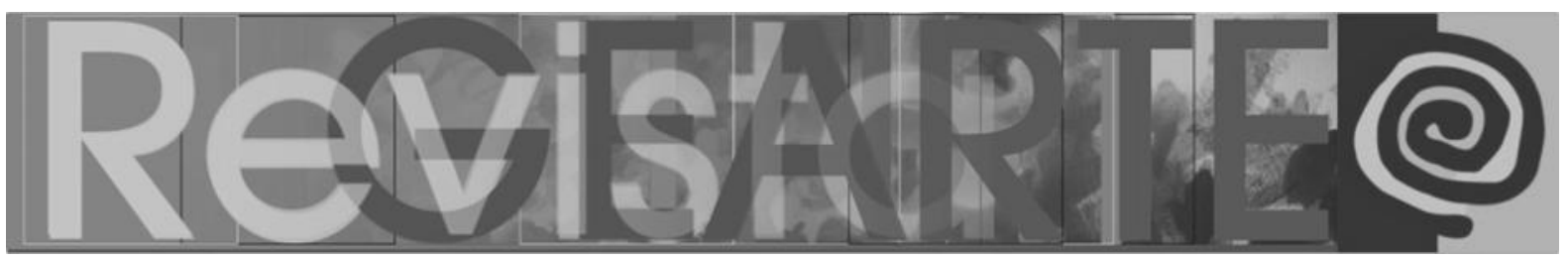

mirada vuelta hacia Europa y Estados Unidos como modelos económicos, sociales y culturales.

El proceso de socialización, de conformación de subjetividad, es concebido por el psicoanalista Pichón Rivière como un largo proceso de aprendizaje que da lugar a la conformación en cada cual de un esquema referencial que va a denominar también "aparato para pensar la realidad". "Aparato" que nos permite, percibir, distinguir, sentir, organizar y operar en la realidad; nos estabiliza en un determinado modo de concebir el mundo. De vivirlo. Y del cual el arte es un instrumento fundamental.

Queda en pie la pregunta inicial. ¿Podrá la Educación por el Arte poner en acto sus principios y objetivos?

Si. Siempre y cuando en América Latina logremos una justa distribución de los bienes sociales. No solo bienes materiales sino bienes en términos de educación, salud, cultura, libertad, autonomía Que los derechos sociales estén igualitariamente distribuidos. Que sean respetadas las contribuciones de todas las culturas sean cuales fuere su origen. Es decir alcancemos el pleno goce de la democracia.

La expansión de la democracia significa la expansión de la ciudadanía participativa, lo único que puede contraponerse al sistema de desigualdades imperante. Construir una sociedad más igualitaria pasa entonces esencialmente por profundizar la democracia, sus mecanismos e instituciones. Por salvaguardar las artes, lo que como ya hemos dicho es lo que da sentido a nuestras vidas, a nuestros sueños.

¿Cuáles deberían ser entonces nuestros objetivos - al decir de Pierre Bourdieu se trata de trabajar en función de un "utopismo racional aplicando el conocimiento de lo probable para promover el advenimiento de lo posible". 


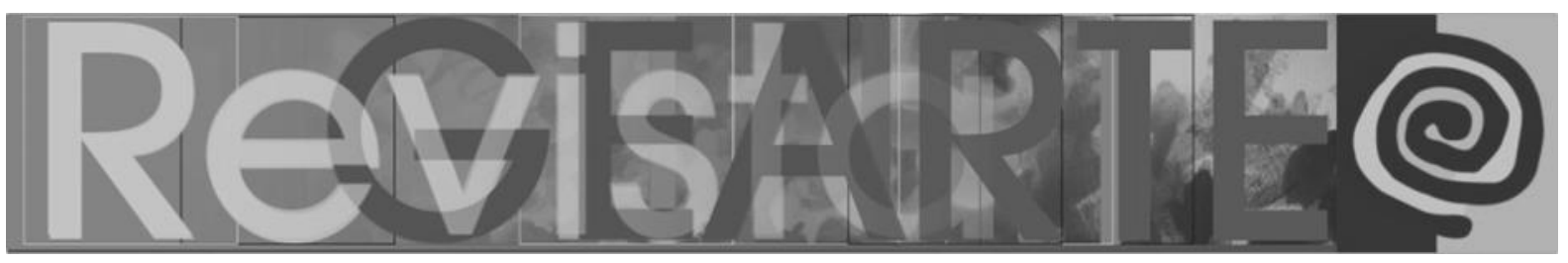

\section{Victor Kon}

Foi incessante batalhador pelas causas da Educação pela Arte, principalmente na América Latina. Tinha diploma superior en Educación, Imagen y Medios de FLACSO. Foi membro da Redação da Revista Virtual "Arte@" de São Paulo, Diretor da Red Multimedial Estrada de Capacitación. Docente do Instituto de Capacitación en Arte y Educación e do Programa "Con ayuda del Arte" do Ministerio de Educación de la Nación. Foi membro do Consejo Latinoamericano de Educación por el Arte (CLEA) desde sua fundação, em 1984, e membro da InSEA - UNESCO. Foi Secretário Geral do CLEA, da Federación Argentina de Teatros Independientes, do Movimiento Argentino de Educación por el Arte, Diretor Geral do Teatro IFT e produtor de Programas Folclóricos e Infantis no Canal 7, entre outros. Fez vários seminários e conferências em diversos países da América Latina. Foi o idealizador da Associação Nueva Mirada, que realiza o Festival Internacional de Cinema "Nueva Mirada" para a Infância e a Juventude", um projeto que conta com o apoio do Instituto Nacional de Cine y Artes da Argentina. Sempre foi atuante nas áreas de Arte e Educação, dirigindo-se às crianças e jovens como cidadãos portadores de direitos e deveres em sua idade $\mathrm{e}$ merecedores de uma educação artística significativa e de qualidade. 